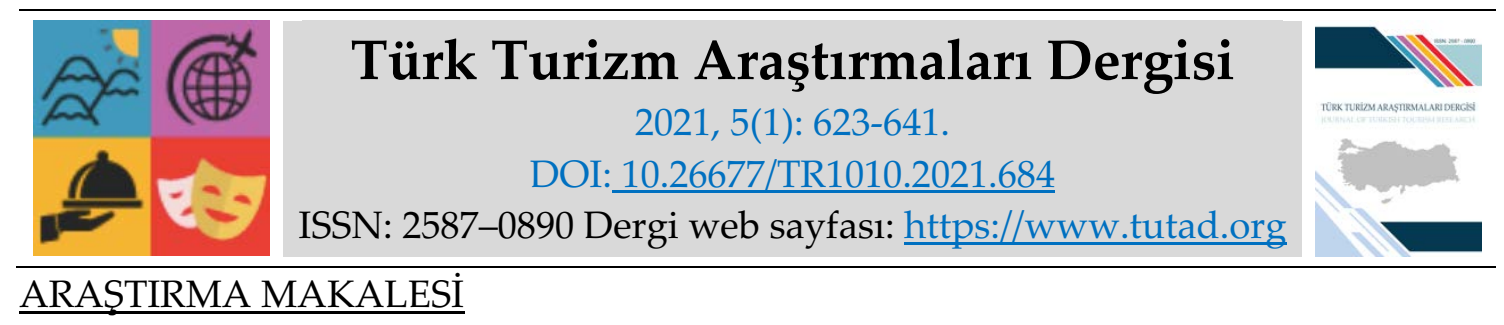

\title{
Yenilenebilir Enerji Teknolojilerinin Konaklama İşletmelerinde Kullanımı ve Turizm Arzındaki Paradigma Kırılması: Avusturya Stadhale Hotel İncelemesi*
}

Dr. Öğr. Üyesi Emirhan YENIŞEHİRLIOĞLU, Alanya Alaaddin Keykubat Üniversitesi, Turizm Fakültesi, Antalya, e-posta: emirhan.yenisehirlioglu@alanya.edu.tr ORCID: https://orcid.org/0000-0002-6856-9506

Prof. Dr. Oğuz TÜRKAY, Sakarya Uygulamalı Bilimler Üniversitesi, Turizm Fakültesi, Sakarya, e-posta: turkay@subu.edu.tr ORCID: https://orcid.org/0000-0002-0752-6799

Öz

Fosil tabanlı yakıt kullanımının, sosyal ve fiziksel çevre açısından sürdürülebilir olmayışı, insanoğlunu ikame yeni enerji türleri arayışına yöneltmiştir. Yüksek enerji performansına sahip akıllı binalar ve çevre dostu yenilenebilir enerji teknolojileri, fosil yakıtlara olan bağımlılı̆̆ımızı azaltabilmemiz açısından önemlidir. Bu teknolojilerin konaklama işletmeleri bünyesinde kullanılması da turizm endüstrisinin daha çevreci bir seviyeye erişmesi ve sürdürülebilir turizm algısının desteklenmesi açısından önemlidir. Araştırma kapsamında Dünyanın ilk \%100 yenilenebilir enerji ile faaliyet gösteren oteli, Boutiquehotel Stadthalle Wien ziyaret edilerek incelenmiş, Avusturya otelciler federasyonu başkanı, otelinin sahibi ve pazarlama müdürü ile mülakatlar gerçekleştirilerek, otelin yatırım ve uygulama süreçleri analiz edilmiştir. Bulgular neticesinde bir otelin hizmetlerinde kısıntıya gitmeden \%100 yenilenebilir enerji ile faaliyet göstermesinin mümkün olmadığı, ancak yenilenebilir enerji teknolojilerinin otel işletmelerine entegrasyonunda bir engelin bulunmadığı tespit edilmiştir.

* Bu çalışma Prof. Dr. Oğuz TÜRKAY danışmanlığında Dr. Öğr. Üyesi Emirhan YENIŞEHIRLIOĞLU'nun "Akıllı Bina ve Yenilenebilir Enerji Teknolojilerinin Konaklama İşletmelerine Entegrasyonu" isimli doktora tezinden üretilmiştir.

Anahtar Kelimeler: Turizm, Yenilenebilir Enerji, Sürdürülebilir Turizm, Enerji Verimliliği. Makale Gönderme Tarihi: 02.01.2021

Makale Kabul Tarihi: 11.03.2021

\section{Önerilen Atıf:}

Yenişehirlioğlu, E. ve Türkay, O. (2021). Yenilenebilir Enerji Teknolojilerinin Konaklama İşletmelerinde Kullanımı ve Turizm Arzındaki Paradigma Kırılması: Avusturya Stadhale Hotel İncelemesi, Türk Turizm Araştırmaları Dergisi, 5(1): 623-641.

(C) 2021 Türk Turizm Araştırmaları Dergisi. 


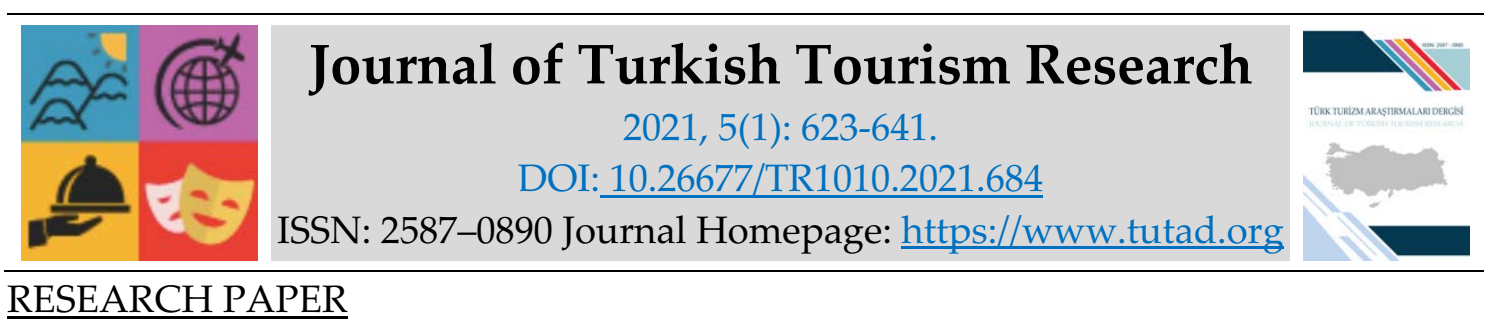

\title{
Utilisation of Renewable Energy Technologies in Hospitality Businesses and Breaking the Paradigm in Tourism Supply: Review of Austria Stadhale Hotel
}

Assistant Prof. Dr. Emirhan YENIŞEHIRLIOĞLU, Alanya Alaaddin Keykubat University, Faculty of Tourism, Antalya, e-mail: emirhan.yenisehirlioglu@alanya.edu.tr ORCID: https://orcid.org/0000-0002-6856-9506

Prof. Dr. Oğuz TÜRKAY, Sakarya University of Applied Sciences, Faculty of Tourism, Sakarya, e-mail: turkay@subu.edu.tr ORCID: https://orcid.org/0000-0002-0752-6799

\begin{abstract}
Due to social and physical environmental unsustainability of fossil-based fuel, mankind diverted focus on new energy sources. Smart buildings and renewable energy technologies are crucial in reducing dependency on fossil fuel. Utilization of these technologies by hospitality enterprises are essential in elevating the tourism industry to an environment- friendly level as well as supporting the perception of sustainable tourism. This study consists of five sections. First section focuses on the relationship between fossil energy and environment, second section relationship between renewable energy and environment, third section Smart Building applications, fourth section examines the certificate programs for environment friendly tourism entities from a sustainability perspective. World's very first hotel that runs by $100 \%$ renewable energy has been visited and the president of Austria hoteliers federation, the owner as well as the marketing manager of the hotel have been interviewed, the investment and implementation processes have been analyzed to the conclusion that it is not possible for a hotel to run $100 \%$ on renewable energy only without cutting down on its room equipment and general services, however there is no obstacle to the integration of renewable energy technologies into hotel operations.
\end{abstract}

Keywords: Tourism, Renewable Energy, Sustainable Tourism, Energy Efficiency.

Received: 02.01.2021

Accepted: 11.03 .2021

\section{Suggested Citation:}

Yenişehirlioğlu, E. and Türkay, O. (2021). Utilisation of Renewable Energy Technologies in Hospitality Businesses and Breaking the Paradigm in Tourism Supply: Review of Austria Stadhale Hotel, Journal of Turkish Tourism Research, 5(1): 623-641.

(C) 2021 Türk Turizm Araştırmaları Dergisi. 


\section{Gíriş}

Gerçekleşen turizm faaliyetlerine bakıldığında, bilinen turizm türlerinin neredeyse hepsinin doğal ya da tarihsel oluşumlardan faydalanacak şekilde tasarlandığı görülebilir. Turizm endüstrisi doğal ve tarihi kaynaklar üzerine kurulu endüstrilerden biridir (Zengin vd., 2009). Bu sebeple turizm endüstrisi kapsamında gerçekleştirilecek tüm hareketliliklerin, çevreye ve doğal hayata saygılı bir şekilde üretilmesi, tükenebilen sınırlı doğal kaynakları koruyarak kullanması bir tercih meselesi olmaktan çok bir zorunluluk, endüstrinin geleceği için belki de en önemli unsurdur.

Ancak sanayi devrimi ile birlikte insan türünü etkisi altına alan tüketim algısı doğal kaynakların hor kullanılmasını da beraberinde getirmiştir (Tıraş, 2012). 1970-2000 yılları arasında endüstrileşme yarışı ile birlikte doğanın ciddi tahribata uğraması, doğal ortamların hızla betonlaşması, hayvan nesillerinin tükenmeye başlaması 2000'li yıllardan itibaren insanların kendi tüketim alışkanlıklarını sorgulamasına sebep olmuştur. Nihayetinde Birleşmiş Milletlerin de yönlendirmeleriyle birçok kurum ve kuruluş insanların tüketim davranışlarından doğan negatif dışsallıkları tespit ederek daha sürdürülebilir bir çevre için gereken önlemlerin alınması hususunda devletler ve kamuoyu düzeyinde bilinçlendirme çalışmaları yapmaya başlamıştır (UN, 2015).

Turizm endüstrisinin hızlı bir şekilde büyüyor olması, turistik hareketlerden doğan çevre zararlarını da kaçınılmaz hala getirmektedir (Nurlu ve Kesgin, 2007). Bu sebeple son yirmi yıldır turizmde sürdürülebilirlik yönünde yapılan çalışmaların sayısı oldukça artmıştır. Yapılan araştırmalar, çevresel tahribatın yaşanmaması için bölgelerin turizme kapatılmasından daha ziyade, planlanan yatırımların yapılacağı yerlerdeki doğal ve sosyal taşıma kapasitelerinin belirlenip, destinasyonların kapasitelere uygun şekilde işletilmesini hedeflemektedir. Amaç, çevreye verilecek zararı en alt seviyede tutarak, ekonomik kalkınmayı sürdürülebilir bir döngü içerisinde devam ettirebilmektir.

Turistik ürünlerin heterojen oluşu (Usta, 2010: 110) bir bölgenin turizm pastasından pay alabilmek için birbirinden farklı yatırım türlerine ihtiyaç duyacağı anlamına gelmektedir. Bu yatırımların belki de en önemlilerinden biri aynı zamanda turizm endüstrisinin bel kemiği sayılan konaklama işletmeleridir (Tarlan ve Tütüncü, 2001: 142). Hizmetlerinin yapısı gereği stoklanamaz olması sebebiyle oteller, talep edilen hizmetleri anında üretmek ve istenen fiziksel ürünleri tedarik edebilecek aracılarla sürekli temas halinde kalmak durumundadırlar. Bu geniş ağ yapısında mekanikleşme minimum düzeyde olduğu için ana unsur insan emeği olarak ortaya çıkmaktadır ki; bu sebeple otel işletmeleri emek yoğun sektörlerin başında gelmektedir (Dilber, 2007: 213). Emek yoğun yani insan enerjisine dayalı olan konaklama işletmelerinde, mekanikleşmenin az olması enerji ihtiyacının az olacağı hissini doğurabilir. Ancak bu düşünce, gerçeği yansıtmamaktadır.

Konaklama işletmelerinin enerji maliyetleri, personel maaşlarından sonra en büyük sabit giderler arasında gösterilebilir. Otel işletmeleri 7 gün 24 saat faaliyet göstermektedirler. Normal iş yerlerinin kapalı olduğu saatler otel işletmeleri için yoğun çalışma saatleridir. Bunun yanında unutulmamalıdır ki bayramlarda ya da resmi tatillerde kepenk indirmeyen bu işletmeler, sürekli şekilde yasayla belirlenmiş hizmet standartlarıyla hizmet vermeye hazır olmak zorundadır. Bünyesinde yüzlerce çalışanı ve binlerce misafiri olan bu işletmelerin; 1sıtma, soğutma, havalandırma, aydınlatma, iletişim gibi temel ihtiyaçların yanında, kat hizmetleri çalışanlarının kullandıkları temizlik araçları, mutfak hizmetlerinde kullanılan ekipmanlar, otomasyon amacıyla kullanılan onlarca çeşit farklı bilgisayar sistemi ve bunların yanında misafirlerin enerji kullanımları otellerin ihtiyaç duyduğu enerji kalemleri arasında gösterilebilir. 
Doğalgaz ve benzer yakıt kullanımlarının da eklenmesiyle birlikte enerji faturası oldukça kabarmaktadır. Enerji giderlerin kısılabilmesi, maliyet avantajı sağlama açısından oldukça önemlidir.

Ancak sürdürülebilirlik perspektifiyle bakıldığında, maliyet avantajıyla birlikte sosyal sorumluluk ve çevreci uygulamalara hizmet eden yatırımların tercih edilmesi bir gerekliliktir. Konaklama işletmelerinin ihtiyaç duyduğu enerjilerin üretilebilmesi için işlenen fosil yakıtların kullanımı neticesinde atmosfere bırakılan karbon gazının, küresel ısınmadan, asit yağmurlarına kadar doğal hayatı tehdit eden birçok olayın başkahramanı olduğu bilinmektedir (Preston ve Jones, 2006, Crutzen, vd., 2007, Zecca ve Chiari, 2010).

Çevreye kalıtsal herhangi bir negatif dışsallık doğurmayan ve yenilenebilir ya da yeşil enerji olarak isimlendirilen, fosil yakıtlara alternatif enerji üretim tekniklerinin günümüzde, nadiren konaklama işletmeleri bünyesinde kullanıldığı bilinmektedir. Çevre ile bu denli içli dışlı olan konaklama işletmelerinin, çevreye zarar vermeyen ve kurulum haricinde maliyeti neredeyse sıfır olan bir enerji türünü üretmesi ve tüketmesi, hem sosyal hem de maliyetler açısından oldukça özendirici olabilecek potansiyele sahip olduğu düşünülmektedir. Bu hem işletme maliyetleri içim olumlu bir gelişme, hem de çevre dostu bir satın alma davranışı sergilemeye başlayan tüketicilerin (Yılmaz vd., 2009) ürün tercihlerinin başka işletmelere kaymaması için önemli bir çekicilik olacaktır.

Bu çalışmada konaklama işletmelerinde sürdürülebilir enerji yönetimi uygulamaları konusunda örnek olabilecek aynı zamanda da güncel çözümleri yansıtacak bir işletme (Boutiquehotel Stadhale Hotel/Viyana/Avusturya) ele alınmakta ve uygulamaları yakından incelenmeye çalışılmaktadır.

\section{KURAM}

Turizm, doğası gereği lüks tüketime teşvik edici bir endüstridir. Yerel halka, işletmelere ve ülkeye ekonomik girdi sağlama amacı ile yürütülmekte, özellikle yabancı turistlerin daha fazla harcama yapması sağlanarak, ülkeye döviz girdisi sağlamak amaçlanmaktadır. Turistlerden kişi başına elde edilen gelirin arttırılması, Türkiye'nin resmi turizm stratejilerinden biridir. Öyle ki, bu durum "Turizm Stratejisi 2023 Eylem Planı" kapsamında dahi ele alınan konular arasındadır (KTB, 2007).

Turizmden elde edilen geliri arttırabilmek birkaç farklı şekilde mümkün olabilmektedir. Bunlar, gelen turist sayısını arttırmak, turistik ürünlerin fiyatlarını yükseltmek ve turistlerin daha fazla tüketim yapmalarını sağlamaktır. Ancak turizm gelirini arttırmak ile sürdürülebilirlik arasında ciddi bir çatışma söz konusudur. Bir destinasyon, gelen turist sayısını arttırmayı planladığında; sürdürülebilirliğin temel taşları olan, fiziki taşıma kapasitesi ve sosyal taşıma kapasitesi sınırlarını aşmak zorunda kalacaktır. Ya da turistlerin daha fazla tüketim yapmalarını sağlamaya çalıştı̆̆ında; sürdürülebilir üretim dengesini bozmak zorunda kalacaktır. Görülebildiği üzere sürdürülebilirlik dengesini sağlayarak, turizm gelirini arttırmak isteyen bir ülkenin elinde sadece turistik ürünlerin fiyatını yükseltme seçeneği kalmaktadır. Ancak turistik ürünlerin fiyatını yükselttiğinde, yaşanılan uluslararası rekabet, turizm talebinin elastik oluşu ve ikame seçeneklerinin fazla olması sebebiyle turist sayısında ciddi düşüşler yaşanabilir. Bu bağlamda sürdürülebilir turizm, özellikle kalkınma açısından, oldukça hassas bir dengede yürütülmesi gereken bir olgudur.

Turist sayısını arttırarak "gelen turistleri sürdürülebilir davranış sergilemeye yöneltmek" bir diğer seçenek gibi görülebilir. Ancak turizm endüstrisi hem lüks tüketime teşvik ederek hem de turistleri sürdürülebilir bir davranış içerisinde tutmayı başarabilir mi? Bu bağlamda turist hareketlerinde bir paradigma kırılması gerçekleşmek zorundadır. Sürdürülebilir bir turizm 
endüstrisine sahip olabilmek için, gelen turistlerin sürdürülebilir tüketim alışkanlıklarını benimsemiş olması gerekmektedir. Aksi halde turizm politika üreticileri ve turizm arz üreticileri tüm sürdürülebilir önlemleri almış olsalar dahi nihai tüketici olan turistler çevreci bir tutum sergilemez ise sürdürülebilir bir turizm endüstrisine sahip olmak mümkün olmayacaktır.

\section{LITERATÜR TARAMASI}

Konaklama işletmelerinin en büyük giderlerinden biri enerji harcamalarıdır (Seyhan ve Yılmaz, 2010, Tutar, 2015). İhtiyaç duyulan bu enerji, büyük oranda fosil kaynaklardan elde edilmektedir (Deng ve Burnett, 2000, Becken vd., 2001). Ancak, fosil enerji kaynakları günümüzde, hem yüksek maliyetleri hem de çevreye zararlı oluşları sebebiyle (York, 2012, Höök ve Tankg, 2013, Jakob, 2015) acilen ikame edilmesi gereken bir ihtiyaç halini almıştır. Fosil yakıt kullanımını akıllı bina teknolojileriyle en aza indirmek, mümkün olduğu durumlarda ise bu ihtiyacı yenilenebilir enerji kaynaklarıyla tümüyle ikame etmek, sürdürülebilirlik eşiğinin aşılmaması açısından önemlidir.

Konaklama işletmeleri bünyesinde yenilenebilir enerji uygulamalarının ne derece kullanılabilir olduğu, lüks tüketimi teşvik eden turizm arzının ne derece yenilenebilir enerji ile karşılanabileceği ve yenilenebilir enerji kaynaklarının işletmenin marka değerine ve müşteri memnuniyetine ne gibi katkılar sağlayacağı halen üzerine çalışılmamış konular arasındadır.

Uluslararası literatür incelendiğinde konaklama işletmeleri bünyesinde yenilenebilir enerji kullanımını inceleyen sadece birkaç çalışma söz konusudur (Karagiorgas vd., 2016; Zografakis vd., 2011; Meschede vd., 2017; Beccali vd., 2018; Navratil vd., 2019) Türkçe literatürde de bu alanda yapılmış akademik çalışma sayısı oldukça azdır. Yapılan çalışmalara büyük çoğunlukla sürdürülebilir turizm kapsamında yeşil pazarlama uygulamalarının konu olduğu görülmektedir (Hacioğlu ve Girgin, 2008, Seyhan ve Y1lmaz, 2010, Atay ve Dilek, 2013). Yenilenebilir enerji ve sürdürülebilir turizm ilişkisini ele alan bir çalışma Akkaya tarafından (2019) kaleme alınmış, benzer konuda bir diğer çalışma da Gümüş ve Örgev (2018) tarafından literatüre kazandırılmıştır. Konaklama işletmelerinin yenilenebilir enerji kaynaklarına karşı tutumu ise Cinel vd., tarafından (2018) incelenmiştir. Ancak, Özgen ve Emeksiz (2009) tarafından kaleme alınan "Konaklama İşletmelerinde Çevre Yönetimi: İber Otel Sarıgerme Park Örneği" isimli çalışma haricinde, konaklama işletmelerinde yenilenebilir enerji kullanımının pozitif ve negatifliklerinin incelendiği detaylı başka bir çalışmaya rastlanmamıştır. Bu alanda yapılan diğer çalışmalar genellikle mimarlık ve mühendislik perspektifiyle ele alınmış, bina tasarımlarında teknik altyapı, kurulum, verimlilik, maliyet gibi konuları ele almaktadır.

Bu çalışma kapsamında yenilenebilir enerji uygulamalarının konaklama işletmelerine entegre bir şekilde kullanılabilmesinin mümkün olup olmadığı araştırılmaktadır. Eğer mümkün ise yatırımların planlama aşamaları, maliyetleri, ne derece etkin oldukları, teori ve pratikteki farklılıklar, misafirlerin konuya bakışı, yapılan yatırımın işletmeye ne gibi katkılar sunduğu, otelin bulunduğu coğrafyaya uygunluğu, yasal zeminin ve endüstrinin ne derece hazır olduğu cevap bulunmak istenilen sorular arasındadır. Kendi enerjisini üretebilen konaklama işletmelerinin tasarlanarak faaliyete girmesi ve yeşil otellere verilen çevreci sertifikalarda (Yeşil Yılzıd, Eco-Label vb.) bu uygulamaların kısmen veya tümüyle yer bulması turizm endüstrisinin sürdürülebilirliği açısından elzemdir.

\section{ARAŞTIRMANIN YÖNTEMI}

Araştırmanın amacı gereği, nitel araştırma yöntemi tercih edilmiştir. Nitel araştırmalar; gözlem, mülakat, doküman analizi vb. tekniklerin kullanıldığı, olayların ve olguların araştırmacının bir 
parçası olarak incelendiği araştırma türü olarak ifade edilmektedir (Yıldırım ve Şimşek, 2008). Ekiz'e göre (2003) nitel araştırmalar, üzerinde araştırma yapılan kişilerin sahip oldukları deneyimlere ait anlamların sistematik olarak incelenebilmesine olanak tanır. Nitel araştırma nicel araştırmanın aksine, insanların olaylara ve olgulara ne tür anlamlar yüklediğini anlamlandırabilmek açısından önemlidir (Dey, 1993).

Çalışmanın veri toplama kısmı için Avusturya Viyana'da bulunan ve Dünyada ilk ve tek \%100 yenilenebilir enerji ile faaliyet gösteren konaklama işletmesi Boutiquehotel Stadthalle'in sahibi, müdürü ve aynı zamanda Avusturya Otelciler Federasyon başkanı olan Michaela Reitterer ile yüz yüze, yarı yapılandırılmış mülakat gerçekleştirilmiştir. Mülakat soruları oluşturulurken, çevreci otellere verilen sertifikaların eksik yönleri ve yapılabilirlikleri incelenmiş, ardından alanında uzman akademisyenler ile görüşülerek tespit edilmesi gereken kritik unsurlar belirlenmiştir. Araştırmacı, verilere derinlik katması ve işleyişi gözlemleyebilmek için otelde 2 gece konaklayarak, Michaela Reitterer eşliğinde tüm oteli gezmiş ve planlamadan, inşaata oradan da yönetimine kadar tüm süreçler hakkında detaylı bilgi edinmiştir. Ardından otelin pazarlama müdürü olan Maria Leifer ile mülakat yapılarak yenilenebilir enerji kullanımının marka değerine etkisi üzerine görüşmeler gerçekleştirilmiştir. Yapılan görüşmeler İngilizce gerçekleştirilmiş, katılımcıların izni dahilinde ses kayıt cihazı ile kaydedilerek, daha sonra içerik analizi ve çözümleme yapılarak Türkçe olarak araştırmaya aktarılmıştır.

Bulgular aktarılırken; tarihsel gelişim, yaşanan problemler, elde edilen faydalar, misafirlerin bakış açısı, işletme sahibi ve müdürünün görüşlerine yer verilmekte, ilgili kısımlarda doğrudan mülakatlardan alıntı yapılarak katılımcıların cümlelerine olduğu gibi yer verilmektedir.

\section{BULGULAR}

Öncelikle Boutiquehotel Stadthalle'in tarihinden ve fiziksel durumundan bahsetmek konunun bütünlüğünü sağlamak açısından gereklidir. Boutiquehotel Stadthalle, Avusturya'nın başkenti olan Viyana şehrinin Hackengasse sokağının 20 numarasında bulunmaktadır. Misafir odalarının kapladığı alan $1.316 \mathrm{~m}^{2 ׳}$ dir ve otel, toplamda $2.271 \mathrm{~m}^{2}$ alana kurulmuştur. Otel 3 yıldıza sahiptir. Otelin 3 yıldızda kalma sebebi uyguladığı sürdürülebilir politikalardır. Bu politikalar bir otelin 5 yıldızlı olabilmesi ile çelişki içerisindedir. Örneğin, tek kullanımlık şampuan yerine şampuan dispanseri kullanılması, havlu ve çarşafların her gün yıkanması yerine misafirin talebi doğrultusunda yıkanması gibi uygulamalar 5 yıldız olabilmek için gereken ve yönetmelik ile belirlenen standartlar ile çatışmaktadır.

Boutiquehotel Stadthalle 19. yy'dan kalma tarihi bir bina ile faaliyete başlamıştır. 2001 yılında bu tarihi bina restore edilmiş, ardından yan bina satın alınarak baştan aşağıya yenilenerek otel bünyesine katılmıştır. 2010 yılında yenilenen kısım hizmete açılmıştır. Otel 2 farklı binadan oluşmaktadır. Eski bina klasik otel anlayışı ile hizmet vermektedir. Yenilenen ikinci binanın özelliği, oldukça az miktarda enerjiye ihtiyaç duyması ve bu enerjinin tümünü yenilenebilir enerji kaynaklarından elde edebilecek şekilde tasarlanmış olmasıdır. Bu yeni çevreci bina bir PassiveHouse örneğidir. Passive-House'lar ya da Türkçe şekliyle Pasif Evler; iyi yalıtıma sahip şekilde, az miktarda enerji kullanarak, \%90 oranında tasarruflu ısınma ve soğuma sağlayan özel yapılara verilen isimlerdir (Yllmaz, 2018).

Her iki binanın renovasyonu kısmen birlikte yapıldığg için toplam harcamanın ortalama 5.400 .000 $€$ olduğu ifade edilmiştir. Bu bağlamda ifade edilmelidir ki dünyadaki ilk ve araştırmanın yapıldığı dönemde de tek \%100 yenilenebilir enerji ile faaliyet gösteren otel Boutiquehotel Stadthalle'dir. 

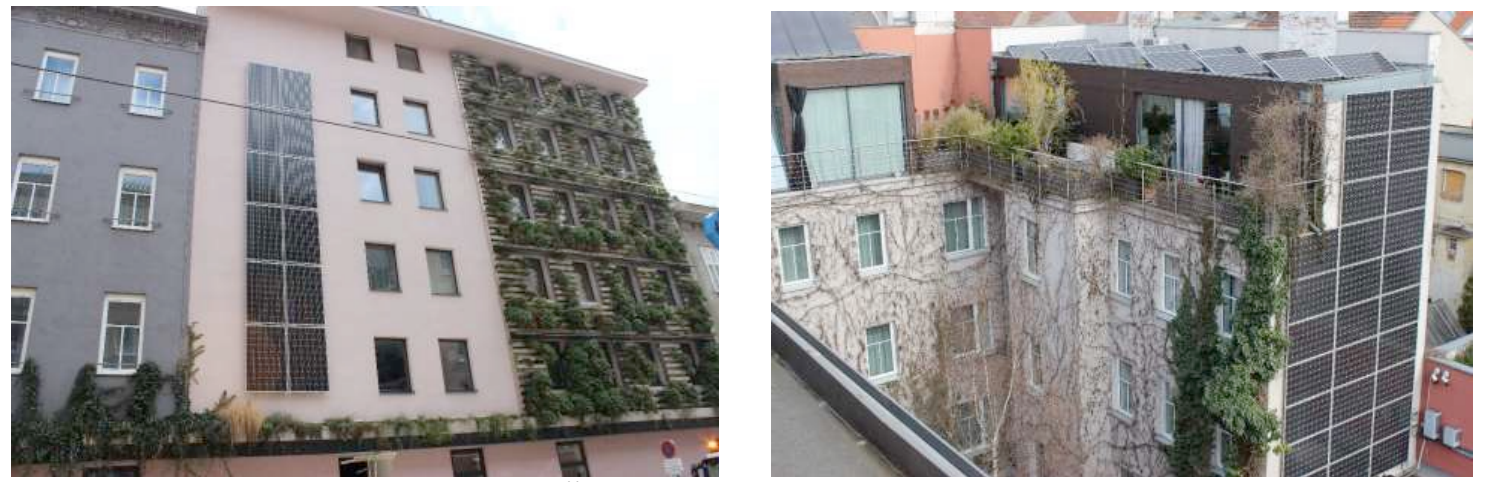

Şekil 1: Boutiquehotel Stadthalle'in Ön Cehpesi ve Arka Cephesi Kaynak: Araştırmacılar Tarafından Fotoğraflanmıştır.

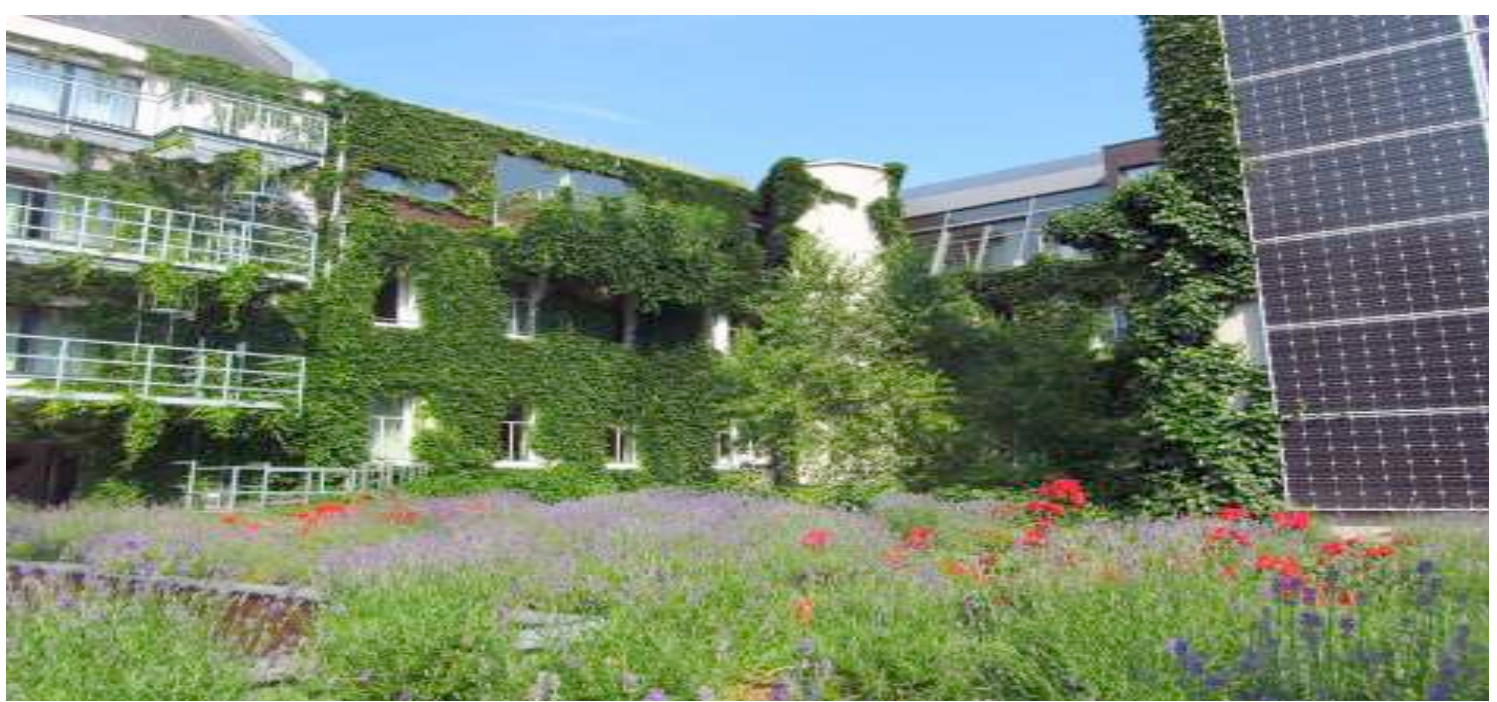

Şekil 2: Boutiquehotel Stadthalle'in İç Bahçesi

Kaynak: hotelstadthalle.at

Otelde toplam 156 yatak, 79 misafir odası bulunmaktadır. Bu odalardan 41 tanesi eski binada, 38 tanesi Passive-House denilen sıfır enerji kullanan yeni binada bulunmaktadır. Her iki bina aynı lobi, restoran ve bahçeyi kullanmaktadır. Tasarruf amacıyla, ışıklandırma sistemi olarak kullandıkları ampullerin \%90'ını LED ampuller ile değiştirmiştir. Geri kalan aydınlatma ise, düşük seviyede enerji tüketen ampullerle karşılanmaktadır. Ortak alanlar fotoselli sisteme sahiptir ve hareket algıladıkları anlarda çalışmaktadırlar. Otelin ulaşım için uyguladığı çevreci politikalar da mevcuttur. İşletmeye tren ya da bisiklet kullanarak gelen misafirler, bileti ya da bisikletinizi göstermeleri halinde \%10 indirim kazanmaktadır.

Otel bünyesinde sadece bir öğün, kahvaltı sunulmaktadır ve kahvaltıda birkaç parça (ekmek, süt, reçel, basit hamur işleri vb.) yiyecek bulunmaktadır. Kahvaltı otelin yeşil algısının bir göstergesi olarak tümüyle yerel ve organik sertifikalı ürünlerden meydana gelecek şekilde hazırlanmaktadır. Yerel ürün bulunamadığı durumlarda ise, organik olmak şartıyla yakın yerleşim yerlerinden ürünler getirilmektedir.

Dikkat edilen bir diğer unsur ise, konaklayan misafirlerin, -olabildiği kadar- çevreci bir algıyla hareket etmesini sağlamaya çalışmaktır. Bu sebeple otelde bulunan, ışıklar dâhil her elektronik cihazın tasarruflu kullanımı ile ilgili bir hatırlatma bulunmaktadır. Aynı şekilde otelde konaklayan misafirlerin kendi çöplerini ayrıştırması beklenmektedir. Bu ayrıştırma otelin diğer 
tüm departmanlarında olduğu gibi, mutfak bölümünde de devam etmektedir. Atıklar katı bir atık ayırma sürecinden geçerek depolanmakta ve ayrı şekilde paketlenerek belediye görevlilerine teslim edilmektedir. Bu sayede geri dönüşüm oranı olabilecek en üst seviyede seyretmektedir.

Su kullanımı açısından 2001 yılındaki yenileme esnasında yerleştirilen yağmur suyu drenaj sistemi, yağmur suyunu biriktirmektedir. Kısmen arındırılan ve depolanan yağmur suyu bahçe sulamasında ve tuvaletlerde (sifonlarda) kullanılmak istenmektedir. Bunun haricinde, ihtiyaç anında şebekeden de su kullanımı gerçekleştirilmektedir.

Elektrik kullanımı miktarları incelendiğinde, Passive-House'un tüm koridorlar ve merdivenlerdeki elektrik tüketiminin en üst seviyede 244 watt olduğu ifade edilmiştir. PassiveHouse içerisindeki tüm odaların ışıkları açıldığı takdirde toplam tüketimin 1344 watt olduğu ölçülmüştür. İfade edilen bu sayı bir evin elektrik ihtiyacından bile kat kat düşük seviyededir. Bu bağlamda aydınlatma alanında enerji kullanım oranlarının tutulabilecek en minimum seviyede olduğu ifade edilebilir.

İşletme sahibi, müdürü ve aynı zamanda Avusturya otelciler federasyonu başkanı olan Michaela Reitterer'nın (metinin devamında "katılımcı" sıfatıyla da yer alacaktır) ifadesine göre Stadthalle butik oteli, 1997 yılında daha ailesi tarafından işletilirken, Viyana'da çevre ödülü alan ikinci işletme olarak kayıtlara geçmiştir. Zaman içerisinde ailesinin de yaşlanması neticesinde katılımcı, sahip olduğu seyahat acentesini satarak 2001 yılında otelin sahipliğini ailesinden almıştır. 2001 yılında ufak bir renovasyon yaparak otele daha çağdaş bir çehre kazandırmaya çalıştıktan sonra 2003 yılında otele entegre ettikleri güneş enerjisi panelleri ile Viyana'daki ilk güneş enerjisi ile su ısıtan otel unvanını da elde etmiştir. Boutiquehotel Stadthalle'in yaptığı bu uygulama kısa süre içerisinde oldukça ilgi çekmiş ve otelin hiçbir ücret harcamadan kendi kendine reklam yapar hale gelmesine sebep olmuştur. Bu durum çevre örgütlerinin de kulağına gitmiş, Boutiquehotel Stadthalle'e çeşitli sertifikalar ile teşekkür mesajları gelmeye başlamıştır.

Buradaki ilginç durum, 2003 yılında güneş enerjisinden su 1sıtma teknolojisi Avusturya için yenilikçi bir durum iken, bu teknoloji 1990'lı yıllardan beri çok yoğun şekilde Türkiye'nin özellikle Akdeniz ve Ege bölgelerinde kullanılmaktadır. Öyle ki bu bölgelerde neredeyse her evin çatısında bir güneş paneline rastlamak mümkündür.

Passive-House da 19.yüzyıldan kalma eski bir binadır. Ancak yapılan projeler eşliğinde, bina kısmen yıkılarak yerine yeni bir bina inşa edilmiştir. Bina proje aşamasındayken katılımcının kafasında "acaba bir oteli ne kadar enerji tasarruflu yapabiliriz" sorusu oluşmuştur. Biraz araştırma ve mimar-mühendis ekibi ile görüştükten sonra, Passive-House olarak isimlendirilen yeni binayı olabildiğince az enerji ile faaliyet gösterebilecek bir bina haline getirmeyi hedeflemiştir.

Bu süreç zarfında farklı fikirler ve ön araştırmalarla birlikte otelin yüksek enerji tasarrufuna sahip olmasının yanı sıra kendi enerjisini üretip üretemeyeceği tartışılmaya başlanmıştır. Birçok mimar-mühendis ve katılımcının arkadaşları, hatta ailesi, bu planın çok mantıklı olmadığını, çünkü dünyada bu şekilde faaliyet gösteren bir otelin daha bulunmadığını, eğer yapılabilir bir uygulama olsaydı başkasının çoktan yapacağını dile getirmişlerdir. Ancak katılımcı, fikrin gerçekleşmemesi önünde hiçbir engel görmediğini, aksine hangi araştırmayı yaparsa yapsın hep olumlu geri dönüşler aldığını ifade etmiştir. Bu bağlamda yeni bina inşa edilirken, eski binanın çatısına güneşten enerji elde etmek için fotovoltaik paneller yerleştirilmiş ve gerekli işletim paneli yeni binanın (Passive-House binasının) bodrumuna yerleştirilmiştir.

Otel önceden planı ve projesi yaptırılan, çatıya entegre edilmesi düşünülen iki rüzgâr tribünü için ilgili izinleri alamamıştır. Bunun sebebi olarak; öncelikle bununla ilgili de bir yasal zeminin bulunmaması, ardından çevredeki diğer sakinlerin bu projeye ret oyu vermiş olmaları 
gösterilmiştir. Rüzgâr tribünleri yüksek ses ve statik elektrik birikimi sebeplerinden dolayı şehir içlerinde kullanıma pek uygun olmayan yatırımlardır. Bu sebeple çevre sakinlerinin neden negatif oy kullandığını anlamak pek de zor olmamaktadır. Bunun yanında görsel olarak da rüzgâr tribünlerinin hoş karşılanmaması olasıdır.

Yeni bina, Passive-House tasarlanırken, odalarda sadece LED ampullerin kullanılması, klima, saç kurutma makinesi gibi elektrikli aletlerin odalara koyulmaması kararlaştırılmıştır. Katılımcımızın ifadesine göre \%100 yenilenebilir enerji ile faaliyet göstermek, \%50-\%50 iki basamaktan oluşmaktadır. \%50'si enerji tasarrufu, diğer \%50'si de yenilenebilir enerji üretimidir. Tasarruf seviyesinin çok yüksek olması gerekmektedir ki, ihtiyaçlar yenilenebilir enerji kaynakları ile karşılanabilsin.

Otel kendi web sitesinde yoğun şekilde vurgu yaparak; Passive-House binasında yer alan odalarda klima, kurutma makinesi, mini-bar gibi elektronik cihazların olmadığını misafirlerine bildirmeye çalışmaktadır. Ancak hala birçok misafirin bu durumun farkında olmadan geldiği ve ilk birkaç dakika içerisinde ya oda değişikliği talep ettiği ya da otelden ayrıldığı ifade edilmektedir.

En üst seviyede enerji tasarrufu elde edebilmek için odalardaki tüm elektronik ekipmanların kaldırılması turist beklentileri ile ne derece örtüşmektedir tartışmasını araştırmanın sonuç kısmına saklamak yapmak faydalı olacaktır.

Odaların tasarımı bittikten sonra hizmete açılmış, bu sürecin ardından yoğun bir takip başlamıştır. Elektrik kullanımları normalde günlük ve aylık olarak hesaplanırken, bu süreçten itibaren saatlik analizler yapılmaya başlanmış ve güneş panellerinden elde edilen enerji ile Passive-House'ın ihtiyaç duyduğu enerji miktarları hesaplanmaya çalışılmıştır.

Gerekli hesaplamalardan sonra güneş panellerinin sadece kağıt üzerinde değil, gerçek anlamda kârlı olabileceği ortaya çıkmış ve yatırım büyütülerek otelin hem yan cephesine hem de ön cephesine fotovoltaik paneller yerleştirilmesine başlanmıştır. Yapılan yatırımlar medyada ve sektörde geniş bir tabana yayılarak hızlı ve pozitif geri dönüşler alınmasına sebep olmuştur. Birçok farklı ülkeden medya kuruluşu, internet siteleri, mimarlar gelerek, otelde incelemeler yapmış ve kendi mecralarında bu verileri yayınlamışlardır. Katılımcının ifadesine göre bu aşamadan sonra birçok yenilenebilir enerji firması otele ulaşarak, ürettikleri yeni ürünlerini test amaçlı otele kurmak istediklerini ifade etmişlerdir. Bu bağlamda inovatif sanayinin de bu otel üzerinde deneyler gerçekleştirdiği ifade edilebilir. Firmaların düzenli olarak katalog göndermeye başlaması, yeni sistemleri denemeleri, kendi mühendislerini göndererek verim arttırma çalışmaları yapmaları, doğal olarak otel için yepyeni bir dünyanın kapılarını aralamıştır.

Ancak bu süreç içerisinde birçok beklenmeyen maliyet ve yasal engellerle karşılaşılmıştır. Katılımonın verdiği rakamlara bakıldığında yaklaşık $250.000 €^{\prime}$ luk bir kayıptan da söz edilmektedir. Bu alanda bir ilk oldukları için örnek alabilecekleri kimsenin olmaması, bazı noktalarda deneme yanılma yönteminin kullanılmasına sebebiyet vermiştir. Örneğin otelin ilk dönemlerinde baktığımızda, Viyana Belediyesi'nin yasaları arasında, yenilenebilir enerji üretilmesi ve tüketilmesi hatta satılmasına dair herhangi bir düzenleme bulunmamaktadır. Bir üst birim ile yazışmalar başlayarak eksiklik giderilmeye çalışılmış olsa da, Stadthalle butik otelin tüm yasal izinleri alması 2015 yılına kadar sarkmıştır. Bu da parası ödenerek çoktan kurulan bazı sistemlerin izin alınamadığı için kullanılamadığı, atıl durumda bekletildiği anlamına gelmektedir. Kaybedilen zaman yapılan tüm başa baş analizlerinin yanlış çıkması anlamına gelmektedir.

Aynı zamanda yenilenebilir enerji üretimi yapan bir otelin, normal bir otele göre 4-5 kat daha fazla izin ve rapor alması gerekliliği, doğal olarak beraberinde ekstra bir maliyeti de 
getirmektedir. Bunun yanında, yaklaşık 20 yıl önce Viyana'da meydana gelen bir otel yangınında birçok misafirin hayatını kaybetmiş olması, Viyana halkının hafızasında yer etmiş durumdadır. Sade ve sakin bir Avrupa ülkesi olarak yaşamına devam eden Avusturya/Viyana'da, yaşanan bu otel yangını, halk arasında büyük bir trajedi şeklinde kabul görmüştür. Bu durum belediyenin ve ilgili birimlerin yenilenebilir enerji üreten bu yeni oteli çok sıkı denetimler ile izlemelerine sebep olmuştur.

Alınan verilere göre kesin olmamakla birlikte sadece Passive-House'ın inşası otalama 4 milyon $\epsilon^{\prime}$ ya mal olmuştur. Bu maliyet içerisine binanın kendisi, odalarda kullanılan ekipmanlar ve yenilenebilir enerji için ihtiyaç duyulan cihazların tümü dahildir. Ancak şu an aynı yatırımın yapılması durumunda çok daha ucuza mal edilebileceği ifade edilmiştir. Bunun sebebi olarak; gelişen teknoloji ile birlikte yenilenebilir enerji cihazlarının fiyatlarındaki düşüş ve birim/verim oranların her geçen gün artması işaret edilmiştir. Yapılan bir diğer vurgu ise, üreticilerin artık gerekli olan ekipmanı madde madde bilmesi, maliyeti düşürebilecek unsurlar arasındadır. Bu bağlamda katılımcı birçok otele danışmanlık vermeye başladığını da ifade etmiştir.

Bahsi geçen 4.000.000€'nun nasıl finanse edildiğine dair alınan bilgilerde, Leasing yönteminin kullanıldığı öğrenilmiştir. Leasing tanım olarak; bir malın leasing şirketi tarafından satın alınması, ardından yatırımcıya belirli bir dönem aralığında kiralanmasıdır. Kiralar bitince mal otomatik olarak kiracıya kalmaktadır (Miller vd., 1976). Bunu bir nevi taksitli bir mal alımı olarak düşünmek mümkündür.

Boutiquehotel Stadthalle'in leasing ödemesinin 20 yıl, 240 ay olduğu da tarafımıza aktarılmıştır. Katılımcıya sorulduğunda, hesaplamalar neticesinde 10-12 yılda yatırımın geri dönüşünün sağlanacağı, 13. yıldan itibaren kar sağlamaya başlayacağı ifade edilmiştir. Ancak bu hesaplar yapılırken o günkü enerji piyasasının fiyatları hesaplamaya dâhil edilmiştir. Aktarılanlara göre, ilk önceleri Rusya'dan alınan doğal gaz fiyatının Avrupa'da zamlanması, hesaplanan bu 10-12 yıllık sürenin 8-10 yıl aralığına düşmesine neden olmuştur. Çünkü enerji fiyatı arttıkça, kendi enerjilerini ürettikleri için normalde enerji alımı için piyasaya verilecek para miktarı şirketin içerisinde kalmaktadır.

Ancak son yıllarda petrol piyasasında yaşanan düşüş, hesaplamaların tamamen yeniden yapılmasına sebep olmuştur. Bu bağlamda değişen enerji fiyatları doğal olarak işletmenin yaptığ başa baş analizlerini etkiler durumdadır. Görüşmenin yapıldığı tarih itibariyle Brent petrol fiyatının tarihin en ucuz seviyelerinde olması nedeniyle işletmenin karlılık hesaplamalarının daha olumsuz bir netice ortaya koyduğu ifade edilebilir.

Kullanılan sistemlerin bakımları ve çalıştırılması ile ilgili yönelttiğimiz soruya cevaben, sistemden sorumlu herhangi bir çalışanın olmadığı ve bu sistemlerin sanılanın aksine oldukça basit ve sağlam sistemler olduğu ifade edilmiştir. Kullanılan sistemlerin ilk günden bu güne kadar en ufak bir sorun çıkartmadığı, zaten cep telefonları için kullanılan aplikasyonlar sayesinde en ufak bir problem oluşmaya başladığı anda bilgi alıp, hemen müdahale edebilecek altyapıya sahip oldukları aktarılmıştır.

Passive-House kurulmadan önce eski binada aylık ortalama $17.000 €$ ila $18.000 €$ arasında bir elektrik giderinin söz konusu olduğundan bahsedilmiştir. Bu eski binada 41 oda bulunmaktadır. Passive-House'un inşasından sonra otele 38 oda daha kazandırılmış olmasına rağmen, aylık ödenen elektrik faturasının hala 17.000€ ila $18.000 €$ arasında olduğu görülmüştür. Bu durum kapasitenin neredeyse 2 katına çıartılıp, enerji olarak herhangi bir tüketim artısının kaydedilmediği anlamına gelmektedir. Kağıt üzerinde Passive-House'un "Zero-Energy Balance" diye ifade edilen, sıfır enerji harcayan bir otel olduğu görülebilir. Ancak resim, sadece kağıt üzerinde bu şekildedir demek pek de yanlış olmayacaktır. 
Otel sahibi tarafından bize verilen bilgileri doğrudan aktaracak olursak, kullanılan yenilenebilir enerji ekipmanlarının aylık ortalama getirisinin $17.000 €$ ile $18.000 €$ arasında olduğu belirtilmiştir. Aslında bu durum büyük bir illüzyonu da beraberinde getirmektedir. Çünkü, oda kapasitesi iki katına çıkartıldığında doğal olarak enerji tüketiminin de aynı şekilde ikiye katlanacağı düşünülmektedir. Fakat, yeni yapılan odalarda mini bar, klima, saç kurutma makinesi gibi elektrik kullanımına ihtiyaç duyan ekipmanların bulunmuyor olması bu odaları diğer odalardan daha az enerji harcar bir konuma getirmektedir.

Öyle ki 41 oda, $17.000 €-18.000 €$ aralığında elektrik harcarken, yeni yapılan 38 pasif odanın da bu seviyelerde enerjiye ihtiyaç duyacağı doğru değildir. "Oda kapasitesi iki katına çıktı, ama enerji tüketimi sabit kaldı, fatura da normalde 2 katına çıkmalıydı" demek beraberinde bazı soruları da getirecektir.

Enerji tüketimi ve üretimindeki maddi tablo bu şekildeyken, enerji üretimi ve satı̧̧ı tablosuna baktığımızda Boutiquehotel Stadthalle'in düzenli olarak sıcak su sattığı ve dönem dönem üretilen elektrik fazlalarını şebekeye sattıkları da not edilmiştir. Bu satışlardan da bir kar elde edilmesi söz konusudur. Ancak alınan bilgilere göre, bazı dönemler ihtiyaç fazlası elektrik üretimi olurken, bazı dönemlerde ihtiyaç duyulan elektrik dahi karşılanamamaktadır. İhtiyaç fazlası dönemde şebekeye satılan elektrik, ihtiyaç duyulan dönemde şebekeden geri alınmaktadır. Ancak burada da ufak bir meblağ kardan zarar yaşanmaktadır çünkü elektriğin satış fiyatı ile alış fiyatı arasında maddi bir fark mevcuttur.

Katılımcının ifadesine göre eğer bu otel Türkiye'de bulunsaydı, iklim özelliklerine bağlı olarak her ay kendi ihtiyacından fazla enerji üretebilirdi. Hatta aktarılana göre, böyle bir durumda pasif binanın haricinde, eski binanın da ihtiyaç duyduğu elektriği yenilenebilir enerji kaynaklarından elde etmek mümkün olabilir. Türkiye'nin bu konuya hızlı şekilde yatırım yapmasının ve içinde bulunduğu enerji darboğazından kurtulması için sahip olduğu değerlerin kıymetini bilinmesi, bir öneri olarak katılımcı tarafından bizlere aktarmıştır. Kuzey Avrupa ülkelerinin güneş sıkıntısı çeken ülkeler olmasına rağmen Dünya'da yenilenebilir enerjinin devleri olarak bilindiği belirtilmiştir.

Gerçekten de Türkiye güneş panellerinden enerji elde edebilmek için adeta biçilmiş kaftandır. Son dönemde bu alana yoğun miktarda yatırım yapıldığı görülmektedir.

Otelin çevreci tutumunun, müşterilere ait enerji kullanımı üzerinde bir farklılık oluşturup oluşturmadığına ilişkin sorduğumuz soruya; "umarım oluşturuyordur, ama bu tamamen eğitimle ve algııla ilgili bir durum, bazı misafirler neredeyse hiç su ve elektrik kullanmadan oteli terk ediyor" şeklinde cevap alınmıştır.

Arap ve Amerikalı turistlerin bir insanın ihtiyaç duyabileceği maksimum ihtiyacın üzerinde elektrik kullandıkları, ancak Arap turistlerin su kullanımlarında en tasarruflu gruplarından biri olduğunun altı çizilmiştir. Bu durum insanların elektrik ve su kullanımlarının yaşadıkları bölgenin şartları ve kültürüyle ilişkili olduğunu işaret etmektedir. Bu husus üzerinde yeni bir araştırma yapılması ilgi çekici sonuçlar ortaya koyabilecek niteliktedir.

Ancak turist algısının her zaman olumlu olmadığını da belirtmek gerekmektedir. Oteldeki odaların kısıtlı şekilde tasarlanmış olması, müşteriler açısından olumsuz şekilde karşılanabilmektedir. $\mathrm{Bu}$ durumu açık şekilde web sitelerinde bildirmelerine rağmen, misafirlerin birçoğu hiçbir fikirleri olmadan otelin yolunu tutmaktadır. Otelin belli bir segmenti olduğunu dile getiren katılımc1, "kimseyi otelde tutmak zorunda değiliz, eğer bir kişi bu işin ruhuna, konseptine hakim değilse zaten bu otelden memnun ayrilabilmesi mümkün değil" ifadelerini dile getirmiştir. 
Yeşil algıya sahip olmanın maalesef maddi olarak zor olduğu da aktarılmıştır. Örneğin; Boutiquehotel Stadthalle kahvaltı sunumunda tamamen organik ve yerel ürünleri sunmaktadır. Yerel ürün bulunamadığı durumlarda, en yakın illerin ürünleri kullanılmaktadır. Avrupa'da organik tarım oldukça pahalıdır, ancak otel bu maliyete girmeye hazırdır. Organik kahvaltı yıl içerisinde toplamda on binlerce Euro'ya mal olmaktadır. Otel yine de bu maliyeti gönüllü olarak karşılamaktadır. Katılımcının ifadesine göre insanlarında bu algıya sahip olması gereklidir. Bu sebeple klimayı ya da mini-barı problem eden insanların algısal olarak farklı bir konumda olduğu ve bu otelde yeri olmadığı ifade edilmiştir.

Araştırmayı gerçekleştirmek için otel rezervasyonu yaparken, diğer otellerin fiyatları ile Boutiquehotel Stadthalle'in fiyatları kıyaslanmıştır. Bir otelin en büyük maliyet kalemlerinden biri olan enerji giderlerinin oldukça düşük, hatta iddialarına göre sıfır noktasında olduğu düşünülürse, bu maliyetsizliğin oda fiyatlarına yansıtılması beklenmektedir. Ancak ilginç şekilde Boutiquehotel Stadthalle'in oda fiyatları benzer 3 ve 4 yıldızlı otellere kıyasla 20-30€ daha fazladır. Bu durum araştırmacıların dikkatini çekmiş ve bu soru Michaela Reitterer'a yöneltilmiştir. Katılımcı, otel gelirinin \%40 kadar bir kısmının personel maaşlarına ayrıldığını ifade etmiştir. Personel devir hızının oldukça düşük olduğunu, otel çalışanlarından hiç kimsenin başka bir otele gitmediğini aktarmıştır. Katılımcının ifadesine göre bu alınan fazla para organik kahvaltıya ve çalışanların maaşlarına gitmektedir. Daha sonraki süreçte otel çalışanları ile görüşürken, bu durumu sorduğumuzda, "evet, dışarıda başka bir otelde aynı pozisyonda çalıştığımız birine göre 150-200€ daha fazla kazanıyoruz" şeklinde yanıtlar alınmıştır. Otelin kendi iç kaynaklarına değer vermesi ve iş gücü devir hızını sıfıra yakın tutabilmesi bir otelin en önemli yönetimsel görevlerinden biridir. Bu sebeple fiyatın yüksek oluşu makul görülebilmektedir.

Doluluk oranının diğer oteller gibi mevsimsel olarak değiştiği ifade edilmiştir. Viyana'nın iş amaçlı seyahatler için önemli bir çekim merkezi olmaması ve ciddi bir turistik çekim unsurunun bulunmamasından dolayı, Mart ayından Aralık ayına kadar dolulukların yüksek olduğunu ancak diğer aylarda düştüğü ifade edilmiştir. Yeşil olmanın otelin marka değerine bir katkısı var $\mathrm{m}$ ? sorusuna ise verilen cevabı direkt olarak aktarmak faydalı olacaktır.

Michaela Reitterer: "Bu otel olmasaydı, dünya çapında bu kadar bilinirliği olmasaydl, yüzlerce ödül almış olmasaydı bir kadın olarak benim Avusturya Otelciler Federasyonu başkanı olabilmem mümkün değildi. Çünkü turizm Avusturya'da; Tirol, Salzburg gibi şehirlerde gerçekleşiyor kış sporlarından dolayı. Viyana'nin geceleme sayısı 14 milyon iken Tirol'ün 46 milyon, Salzburg'un ise 26 milyon gecelemesi oluyor. Tüm sezona baktı̆̆ımıza bu kuzey şehirlerinin gecelemeleri 85.000.000'a ulaşabiliyor. Viyana'nınki ise sadece 14.000.000. Bu kadar ciddi bir fark varken o işletmelerin arasından, o insanların arasından sıyrılarak bu noktaya gelmem mümkün değildi.

Boutiquehotel Stadthalle, Avusturya genelinde bilinen ve saygl gören bir otel. Düşündüğ̈̈̈nde, Türkiye gibi başka bir coğrafyadaki, akademisyen, oralardan, beni ismen bilerek mail atarak randevu talebinde bulunuyor. Bu benim yaptı̆̆ım işi düzgün yaptı̆̆ım anlamına geliyor. Aksi halde Türkiye'deki seyahat acenteleri bile benim varlığımdan habersiz olacaktı. Bu kadar yüksek bir bilinirliği elde edebilmek için bütçenizin tamamını reklam faaliyetlerine ayırmanız gerekmektedir ki belki bu bile yetmeyebilir. Ben ve otelim tek kuruş para harcamadan dünyanın her yerindeki ekolojik mimari dergilerinde, turizm dergilerinde, gazetelerde, haberlerde, hatta ders kitaplarında kendimize yer bulabiliyoruz ve bu yayılarm hepsi bizden övgüyle bahsediyor. Bu çok ciddi bir reklam anlamina gelmektedir. Milyon Euro'lar ödeyerek elde edilemeyecek bir reklam değerinden bahsediyorum. Marka güvenilirliğini saymıyorum bile.

-Peki bu durum, diğer işletmelerin sizi taklit etmesine, bu pastadan faydalanmak istemelerine sebep olmuyor mu? sorusuna şu yanıt verilmiştir. 
"Umarım oluyordur, bu çeore açısından oldukça güzel olurdu. Ancak normalde otel sermayesi ile yönetici farklı kişilerden oluşuyor. Zincir otellerde ise bu durum bambaşka. Ancak ben burada kendi ekibim ile karar alıp harekete geçebiliyorum. Zaten yap olarak oldukça esnek bir organizasyonuz. Sadece Avusturya'da 20'ye yakın Eco-Etkiet var otellere verilen. Mesela biz de kendi eco-etiketimizi oluşturduk. Biz ve 4 benzer otel daha Sleep Green Hotels diye bir sertifikasyon yarattık. Bu bildiğimiz sertifika programlarmnn bir basamak ilerisi olacak. Hali hazırda Almanya'da ve Avusturya'da 14 otel bu sertifikayı almaya hak kazandı. Her departmanin iç işleri için Green Pillow uygulaması var, bu Green Pillow'lar toplamda Sleep Green puanını oluşturuyor. İçerisinde elektrik kullanımı, su kullanımı, kağıt kullanımı birçok alt madde mevcut. Her otel yeşil olmaya çalışıyor aslında. Örneğin; dünyadaki en büyük turizm web sitelerinden biri Tripadvisor.

Bu site de kendisine göre bir yeşil sertifika oluşturmuş durumda. Ĕger bu sertifikayı alabiliyorsanız, web sitesinde sizden oldukça güzel övgüler ile bahsediyorlar. Biz bu sertifikanın da Platinium seviyesini, yani en üst seviyesini alabildik. Fakat bu sertifika programlar hep birbirinin benzeri. Artık sertifika sahibi olmak yeşil olunduğu anlamına gelmiyor. Şöyle söyleyebilirim, mesela sizin kaldığınız odadaki perdelerden, yatak çarşaflarına, yastık kılıflarına hatta halılara kadar tüm ürünler geri dönüştürülmüş ürünler. Dünya'da bu, pek rastlanılmayan bir durum.

Bunu yanında oteli gezerken göreceğiniz üzere bazı odalarımızdaki tüm mobilyalar ve eşyalar, geri dönüşmüş̧ ürünler ile yapılmış durumda. Bunlarda tamamen geri dönüşüm malzemeleri ile yapılmış odalar ve söylemekten çekinmiyorum birçok parça çöp olarak atılan materyallerden yapıldr. Bu bazı kişileri rahatsız edebilir ama dünyanın buna ihtiyacı var. Ĕ̆er siz ve ben kendi ihtiyaçlarımızdan kısmazsak, başkasının hakkını gasp ederek ihtiyaçlarımızı karşılamaya başlarız ki bu da dünyanın bu günkü problemi değil mi? Mesela Caritas programı var hiç duydunuz mu bilmiyorum, bu program mültecilere iş bulmaya çalışan sosyal sorumluluk programı. Suriyeli mülteciler için geri dönüştürülmüş mobilya programı başlattık. Eski mobilyaları alarak, tadilattan geçirip yepyeni hale getirip tekrar satıyoruz, böylece mültecilerin para kazanabilmesini sağlıyoruz. Odalarımızdan bir tanesi bu şekilde. Eskiyen eşyalarımızı da doğrudan Caritas'a bağışıyoruz ki tekrar üretip satabilsinler. Ürettikleri bu mobilyaları Carla isminde bir şirket ismiyle satıyorlar. Bu döngü hem geri dönüşüme hem de insan hayatına önem veren bir proje. "

\section{Analiz ve Bulguların Değerlendirilmesi}

Boutiquehotel Stadthalle; yeşil bir otelin sınırlılıklarının algılanabilmesi açısından güzel bir örnektir. Hem yönetim hem de mülkiyet açısından çevre algısı oldukça yüksek olan bu otel, bilinen ve geliştirilen her türlü teknolojiyi bünyesinde kullanmaya hazır bir görüntü vermektedir. Zaten yukarıda bahsedildiği gibi dünya tarafından bilinen bir otel olunması ister istemez otelin karakterine de bir sorumluluk yüklemiş durumdadır. Bahsedilen sorumluluk, çevreci algının sürekli daha ileriye taşınma misyonudur. Otel sahibi ve müdür Michaela Reitterer yatırımların devamının geleceği noktasında çok açıktır. Bu bağlamda otelin dünyadaki en çevreci otellerden biri olduğu aşikardır. Aldığı ödüller de bu ifadelerimizi kanıtlar niteliktedir.

Ancak sorgulanması gereken birkaç unsur da mevcuttur. Mülakatı gerçekleştiren araştırmacının düşüncelerine göre, kamuoyu ile paylaşılan veriler aslında tam olarak gerçeği yansıtmamaktadır. Veriler çok uygun şartlar sağlanarak, en iyimser senaryonun yaşandığı bir gün için geçerli olabilecek sayılardır. Böyle düşünülmesinin sebebi ise birkaç şekilde açıklanabilir.

Bunlardan ilki; otelin ısıtması için kullanılan sistemleridir. Bu nokta oldukça elzemdir çünkü sadece bu veri bile otelin "Zero-Energy Balance" sloganını zedeleyebilecek güçtedir. 
Bahsettiğimiz gibi Stadthalle otel iki binadan oluşmakta, bunların ilki eski bina, ikincisi ise Passive-House denilen yüzde yüz yenilenebilir enerji kullanan yeni binadır. Passive-House ve eski bina gibi yerden 1sıtmalıdır. Kritik nokta şudur ki; Passive-House' un 1sıtma sistemi ile eski binanın ısıtma sistemi tek merkezden yönetilmektedir. Bu iki sistem aslında 1 ana isitıcının iki farklı binaya ulaştırılmış halidir. Bu ana ısıtıcı eski binada bulunmaktadır. Bu süreçte iki binanın da 1sıtılmasını için kullanılan enerji, sanki Passive-House'un ssınmak için herhangi bir enerji tüketmiyormuş gibi görünmesi amacıyla eski binanın enerji kullanım hanesine yazılmaktadır. Ancak Passive-House, eski binada harcanılan enerji ile 1sitılmaktadır. Aslında Passive-House'un 1sıtılması için kullanılan enerjinin Passive-House kullanım hanesine yazılması gerekirken, matematiksel olarak sırf Passive-House'un enerji kullanımı düşük çıksın diye bu kullanım, sanki eski binaya aitmiş gibi gösterilmektedir. Bu veriler ile oynamaktan başka bir şey değildir.

Stadthalle otele getirilecek bir diğer büyük eleştiri de odalardaki elektronik ekipman eksikliğidir. Eleştirilerden ilki; bilindiği gibi konaklama işletmeleri yapısı gereği lüks tüketime elverişli ve lüks tüketimin desteklendiği işletmelerdir. Bu tip tüketimler konaklama işletmelerinin temel gelir kaynakları arasındadır. Misafirleri, sadece minimal ihtiyaçlarını karşılayarak ağırlamak, konaklama işletmelerinin mevcut paradigması ile çelişmektedir. Çünkü kişiler tatillerinde ve yüksek ücret ödeyerek konakladıkları otellerde kendilerini özel hissetmek istemektedirler. Evlerinde sahip oldukları standartların da altında bir standart ile karşılaşılması, muhtemelen turistlerin birçoğunda rahatsızlık yaratacaktır. Zaten mülakatlar neticesinde elde edilen bulgular da bu düşüncelerimizi destekler niteliktedir. Bu husus üzerine yeni araştırmaların yapılması gereken bir alandır.

Bununla birlikte Viyana genel olarak Türkiye'ye kıyasla yüksek sıcaklıklara çıkmayan bir coğrafyada bulunmaktadır. Bu tip bir iklime sahip iken odalarda klima ve mini-barın bulunmaması bir nebze olsun tolerans gösterilebilecek bir durum olarak kabul edilebilir. Ancak aynı senaryoyu Türkiye' de uygulamaya koyduğumuzda, yaz aylarında, hatta ilkbahar aylarında klima ve buzdolabı olmadan Antalya, Mersin, Şanlıurfa, Kaş, Didim, Bodrum gibi şehirlerimizde tatil yapabilmek pek mümkün görülememektedir. Bu şehirlerde yaz aylarında gündüz sıcaklık $45^{\circ}-50^{\circ}$ dereceye ulaşabilmektedir. Bu bağlamda yenilenebilir enerji kullanan otellerin, fazla elektrik kullanan ekipmanları ortadan kaldırmaları sıcak iklim koşullarında pek mümkün görünmemektedir.

Otelin incelenmesi sırasında esnada farkına varılan bir diğer unsur ise, neredeyse tüm çevre değerlendirme sertifika programlarında bulunan "yağmur suyunu tekrar kullanma" sorusu ile ilişkilidir. Sertifikalarda bu suyun bahçe sulaması ve sifonlarda kullanılabileceğinden bahsedilmektedir. Stadthalle otelde yağmur suyunu tekrar kullanabilmek amaciyla gerekli yatırımı yapmıştır.

Ancak pazarlama müdürü Maria Leifer eşliğinde otel incelenirken, yağmur suyu depolamasının sanıldığının aksine, ciddi şekilde problemli bir uygulama olduğu tarafımıza aktarılmıştır. Öyle ki, yağış esnasında şehrin kirli havasına maruz kalarak yere inen yağmurlar toplanılarak üstteki fotoğrafta görünen tanklarda biriktirilmektedir. Bu tanklarda biriktirilen su, çok kısa süre içerisinde yoğun miktarda bakteri üremesine sebebiyet vermektedir. Toplanmasının hemen ardından kokmaya başlayan bu su, otelde sifon ve benzer alanlarda kullanılmak için sisteme verildiğinde, bütün oteli kesif bir rutubet kokusu sarmakta ve sifonlardan kahverengine yakın kirli bir su akmaktadır. Bu durum misafirlerden önce otel personelini rahatsız etmektedir. Maria, ilk birkaç denemeden sonra ciddi koku şikâyetleri aldıklarından bahsetmiştir. Bu sebeple bu uygulama pek de pozitif bir getiriye sahip değildir. 


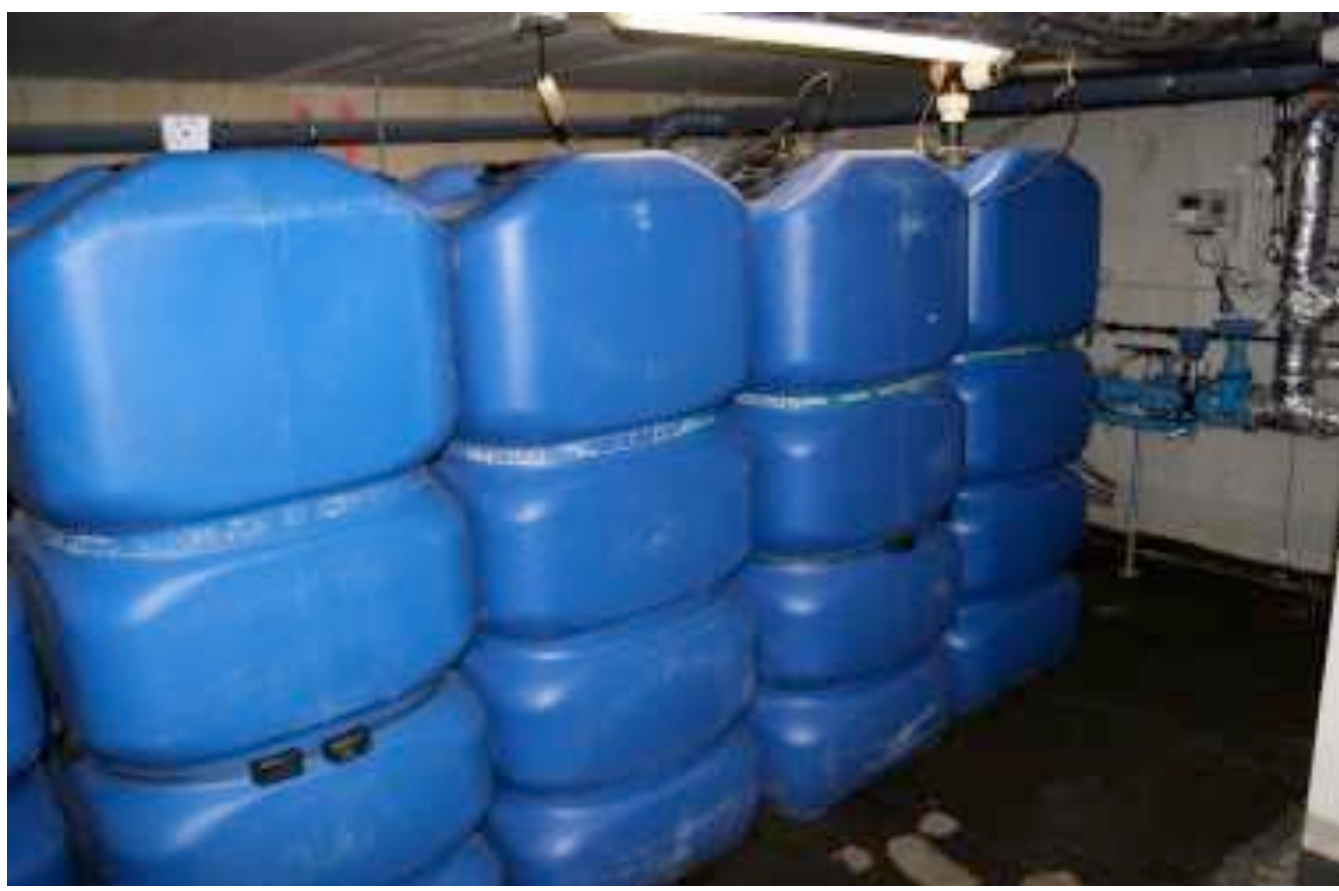

Şekil 3: Yağmur Suyu Depolama Tankları

Kaynak: Araştırmacılar Tarafından Fotoğraflanmıştır.

Buradan bir çıkarım yaparak kullanılan sertifika programlarının teori ile pratik kısmının örtüşeceği yeni bir seviyeye getirilmesindeki ihtiyaca bir kere daha vurgu yapılabilir.

\section{SONUÇ ve DEĞERLENDİRME}

Fiziksel ve sosyal çevre açısından bakıldığında dünya, her geçen gün daha kötü bir yer halini almaktadır. Bu gidişatın sebebi, kimi zaman farklı din görüşleri, kimi zaman farklı siyasetler kimi zaman da doğrudan sermayenin kendisidir. Ancak sebebi ne olursa olsun, bu gidişattan zarar gören ortak kesim dünya üzerinde yaşamını sürdürmeye çalışan tüm canlılardır. İster insan olsun, ister okyanusta yüzen bir kaplumbağa tüm türler aynı yer küreyi paylaşmak durumundadir.

Bu kaotik gidişata "kısmen" dur diyebilmek ve içerisinde yaşadığımız dünyanın bize sağladığı güzelliklere, bizden farklı görüşlere sahip insanlara, kısacası hayatımızı sürdürdüğümüz tüm fiziksel ve sosyal çevrelere saygı gösterilerek sahip çıkılması ve hiçbir canlıya zarar vermeden elimizdeki imkânları olabildiğince verimli kullanmamızı hedefleyen yaklaşım türüne Sürdürülebilirlik Yaklaşımı denilmektedir.

Sürdürülebilirlik yaklaşımı prensip olarak, içinde bulunduğumuz çevreyi bizden sonraki nesillerinde en iyi şekilde faydalanabilecekleri bir halde bırakma isteğidir. Böylece; uzun vadeli ve çevreyi paylaştığımız bitki-hayvan tabiatına saygılı hassas bir ilişki kurulması amaçlanmaktadır. Çünkü çevreye kendini yenilemesine fırsat verilmezse, bir noktadan sonra etrafımızda bir çevre kalmayacaktır. Maalesef ki dünyamızın bu günkü gidişatı birçok alanda sürdürülebilirlik felsefesinden oldukça uzaktır.

Turizm araştırmacıları, olarak bizlerin elinde dünyayı baştan aşağıya değiştirebilecek bir güç ve yetki yoktur. Ancak Alman edebiyatçı Goethe'nin söyleminde bahsettiği “herkes kendi kapısının önünü süpürse, her semt temiz olur" sözü unutulmamalıdır. Bizler, turizm araştırmacıları olarak en 
azından kendi kapımızın önünü süpürerek dünyanın daha temiz bir yer olması için katkıda bulunmak zorundayız. Bu bağlamda turizm endüstrisini şu anki durumdan bir adım öteye götürerek, daha yeşil ve daha sürdürülebilir bir algıya yaklaştırma çabası, bizler için uğrunda emek sarf edilebilecek bir amaçtır.

$\mathrm{Bu}$ araştırma kapsamında turizm endüstrisinin bel kemiği kabul edilen konaklama işletmelerinin çevreye duyarlılık açısından hangi seviyede olduğu ve enerji kullanımlarının fosil yakıtlardan yenilenebilir enerji kaynaklarına geçip geçemeyeceği tespit edilmeye çalışılmıştır.

Bir otelin çevrecilik üst sınırının belirlenmesi, beklentilerin somutlaştırılması ve geleceğin tahmin edilebilmesi açısından önemlidir. Bu bağlamda \%100 yenilenebilir enerji ile faaliyet gösteren Avusturya Viyana'da bulunan Boutiquehotel Stadthalle' in incelenmesi bize ihtiyaç duyduğumuz verileri sağlamıştır. Otel sahibi ve Avusturya Otelciler federasyon başkanı Michaela Reitterer ile yaptığımız görüşmeler neticesinde yenilenebilir enerji teknolojilerinin konaklama işletmelerinde kullanılabildiğini, herhangi çözülemeyecek bir sorun ile karşılaşılmadan bu teknolojilerin kurularak faaliyete girebildiği belirlenmiştir. Ancak yasal prosedürlerin hala yenilenebilir enerji teknolojilerinin gerisinde kalıyor oluşu bu alandaki önemli sıkıntılardan biri olarak ifade edilmiştir. Boutiquehotel Stadthalle'de konaklarken elde ettiğimiz veriler incelendiğinde; bir otelin gerçek anlamda misafirlerin, lüks tüketim de dâhil tüm ihtiyaçlarını karşılayarak \%100 yenilenebilir enerji kullanarak hizmet vermesi günümüz teknolojileri ile pek de mümkün görünememektedir. Boutiquehotel Stadthalle odalardan klima, mini-bar, saç kurutma makinesi gibi ekipmanları kaldırarak odalarda neredeyse sadece 2 1şık düğmesi bırakarak \%100 yenilenebilir enerji seviyesine ulaşabilmiştir. Ancak bu seviyeyi de yılın tüm zamanları için koruyabildiğini söylemek mümkün değildir.

Ayrıca Türkiye gibi sıcak iklime sahip bir ülkede otel odalarından klima ve mini-barları kaldırmak maalesef gerçekçi ve sürdürülebilir bir senaryo olmayacaktır. Zaten Boutiquehotel Stadthalle' de konaklayan misafirlerin birçoğu bu kısıtlamalardan memnun olmadıklarını da dile getirmektedirler. Bu iki görüşün birbiriyle aynı noktayı işret ediyor oluşu, bulgularımızın sağlaması niteliğindedir.

Aynı şekilde Antalya'da faaliyet gösteren yüzme havuzlu bir otel ile Viyana'daki bir şehir otelinin su kullanım miktarları da birbirinden oldukça farklı sonuçlar verecektir.

Son olarak ifade edilmelidir ki, günümüz teknolojileri ve misafir algısı, bir otelin herhangi bir kısıtlamaya gitmeden üst standartta hizmet vererek, ihtiyaç duyduğu tüm enerjiyi kendi binasına entegre ettiği yenilenebilir enerji kaynaklarından üretebilmesi mümkün görünmemektedir. Birim/Verim oranları buna izin vermemektedir. Ancak zaman içerisinde yenilenebilir enerji teknolojilerinin gelişmesi bu senaryoyu değiştirebilecek gücü bünyesinde barındırmaktadır. Teknolojik gelişmelerin bu potansiyele en kısa sürede ulaşması, dünyanın başına uzun zamandır dert açan enerji sektörünün, çevre üzerindeki baskısını yok edilebilmesi açısından önemlidir. Bununla birlikte turistlerin satın alma davranışlarında daha çevreci bir tutum sergilemesi, konaklama işletmelerini daha çevreci bir seviyeye ulaşmak zorunda bırakacaktır. Pazar odaklılık bunu gerektirmektedir. Çevre dostu otel sertifika programlarına gerekli devlet desteklerinin de sağlanmasıyla, konaklama işletmelerinin çok daha sürdürülebilir bir seviyede hizmet verebilmesinin önünde hiçbir engel bulunmamaktadır. 


\section{KAYNAKÇA}

Akkaya, F. A. (2019). Sürdürülebilir Turizm Gelişiminde Yenilenebilir Enerji Kooperatifleri, Kemaliye Özelinde Örnek Yatırım Analizi ve Finansal Katkı Değerlendirmesi. Turkish Studies, 14(4), 2003-2028.

Altunışık, R., Batman, O., Halis, M., Zengin, B., Demirkol, Ş., Sobalı, H. ve Türkay, O. (2009). Turizm İşletmeleri, Editörler: B. Zengin ve Ş. Demirkol, Değişim Yayınları, İstanbul.

Atay, L., ve Dilek, S. E. (2013). Konaklama İşletmelerinde Yeşil Pazarlama Uygulamaları: Ibıs Otel Örneği. Suleyman Demirel University Journal of Faculty of Economics and Administrative Sciences, 18(1), 203-219.

Beccali, M., Finocchiaro, P., Ippolito, M. G., Leone, G., Panno, D., and Zizzo, G. (2018). Analysis of some renewable energy uses and demand side measures for hotels on small Mediterranean islands: A case study. Energy, 157, 106-114.

Becken, S., Frampton, C., and Simmons, D. (2001). Energy Consumption Patterns in The Accommodation Sector: The New Zealand Case. Ecological Economics, 39(3), 371-386.

Cinel, M. O., Karaman, G. ve Kabacık, M. (2018) Konaklama İşletmelerinin Alternatif Enerji Kaynaklarına İlişkin Tutum ve Davranışları; Ordu ve Giresun Örneği. Bilge Uluslararası Sosyal Araştırmalar Dergisi, 2(2), 48-58.

Crutzen, P. J., Mosier, A. R., Smith, K. A., and Winiwarter, W. (2016). N 2 O Release from AgroBiofuel Production Negates Global Warming Reduction by Replacing Fossil Fuels. In Paul J. Crutzen: A Pioneer on Atmospheric Chemistry and Climate Change in The Anthropocene (pp. 227-238). Springer, Cham.

Deng, S. M., and Burnett, J. (2000). A Study of Energy Performance of Hotel Buildings in Hong Kong. Energy and Buildings, 31(1), 7-12.

Dey, I. (1993). Qualitative Data Analysis: A User-Friendly Guide for Social Scientists. Routledge Publications, London.

Dilber, İ. (2007). Turizm Sektörünün Türkiye Ekonomisi Üzerindeki Etkisinin Girdi Çıktı Tablosu Yardımıyla Değerlendirilmesi. Yönetim ve Ekonomi Dergisi,14(2), 205-220.

Ekiz, D. (2003). Eğitimde Araştırma Yöntem ve Metotlarına Giriş. Anı Yayıncılık. Ankara.

Gümüş, İ., ve Örgev, C. (2018). Konaklama Sektöründe Yenilenebilir Enerji Kaynaklarının Kullanımı ve Sürdürülebilirlik Açısından Turizme Olan Ekonomik Etkileri. Uluslararası Türk Dünyası Turizm Araştırmaları Dergisi, 3(1), 73-84.

Hacıoğlu, N., ve Girgin, G. (2008). Sürdürülebilir Turizm Kapsamında Yeşil Pazarlamanın Yeri ve Önemi. 13. Ulusal Pazarlama Kongresi" Sürdürülebilirlik ve Pazarlama" Bildiri Kitabı (ss. 417-422), Düzenleyen Çukurova Üniversitesi İ̈ BF, Adana, 30.

Höök, M., and Tang, X. (2013). Depletion of Fossil Fuels and Anthropogenic Climate Change-A Review. Energy Policy, 52, 797-809.

https://www.hotelstadthalle.at/ (Erişim Tarihi, 17.07.2015).

Jakob, M., and Hilaire, J. (2015). Climate Science: Unburnable Fossil-Fuel Reserves. Nature, 517(7533), 150-152. 
Karagiorgas, M., Tsoutsos, T., Drosou, V., Pouffary, S., Pagano, T., Lara, G. L., and Mendes, J. M. M. (2006). HOTRES: Renewable Energies in The Hotels. An Extensive Technical Tool for The Hotel Industry. Renewable and Sustainable Energy Reviews, 10(3), 198-224.

Kültür ve Turizm Bakanlığı (2007). Türkiye Turizm Stratejisi 2023, Eylem Planı 2007-2023. TC Kültür ve Turizm Bakanlığı Yayınları, (3085).

Meschede, H., Dunkelberg, H., Stöhr, F., Peesel, R. H., and Hesselbach, J. (2017). Assessment of Probabilistic Distributed Factors Influencing Renewable Energy Supply for Hotels using MonteCarlo methods. Energy, 128, 86-100.

Navratil, J., Picha, K., Buchecker, M., Martinat, S., Svec, R., Brezinova, M., and Knotek, J. (2019). Visitors' Preferences of Renewable Energy Options In "Green" Hotels. Renewable Energy, 138, 1065-1077.

Nurlu, E. ve Kesgin, B. (2007). Turizm Çevre İlişkisi: Dünyada Turizm Hareketleri. Gökyüzüne En Yakın Bitkiler Alpin Çiçekler Projesi Flora Turizmi, Eğitim Programı Bildiriler Kitabı. Erzurum.

Özgen, I., ve Emeksiz, M. (2009). Konaklama İşletmelerinde Çevre Yönetimi: İ̉er Otel Sarıgerme Park Örneği. Seyahat ve Otel İşletmeciliği Dergisi, 6(4), 50-59.

Preston, B. L., and Jones, R. N. (2006). Climate Change Impacts on Australia and The Benefits of Early Action to Reduce Global Greenhouse Gas Emissions (p. 41). Australia: CSIRO.

Seyhan, G., ve Yılmaz, B. S. (2010). Sürdürülebilir turizm kapsamında konaklama işletmelerinde yeşil pazarlama: Calista Luxury Resort Hotel. Dokuz Eylül Üniversitesi İşletme Fakültesi Dergisi, 11(1), 51-74.

Tarlan, D., ve Tütüncü, Ö. (2001). Konaklama İşletmelerinde Başarım Değerlemesi ve İş doyumu Analizi. Dokuz Eylül Üniversitesi Sosyal Bilimler Enstitüsü Dergisi, 3(2), 141-163.

Tıraş, H. (2012). Sürdürülebilir Kalkınma ve Çevre: Teorik Bir İnceleme. Kahramanmaraş Sütçü İmam Üniversitesi İktisadi ve İdari Bilimler Fakültesi Dergisi, 2(2), 57-73.

Tutar, F. K. (2015). Yeşil Ekonomi, Yeşil Turizm: Türkiye'de Turizm Sektöründe Yeni Trend Yeşillenen Oteller Projesi. Akademik Sosyal Araştırmalar Dergisi, 3(13), 328-352.

UN (2015). The 2030 Agenda for Sustainable Development, Transforming Our World: The 2030 Agenda for Sustainable Development A/RES/70/1, United Nation.

Usta, Ö. (2001). Genel Turizm. Anadolu Matbaacılık, İzmir.

Yıldırım, A., ve Şimşek, H. (2006). Sosyal Bilimlerde Nitel Araştırma Yöntemleri. Seçkin Yayıncılık.

Yllmaz, V. (2018) A New Dimension in Energy Saving: Passive House Enerji Tasarrufunda Yeni Bir Boyut: Pasif Ev. SETSCI Conference Indexing System, 3, 1053-1056

Yılmaz, V., Çelik, H. E., ve Yağızer, C. (2009). Çevresel Duyarlılık ve Çevresel Davranışın Ekolojik Ürün Satın Alma Davranışına Etkilerinin Yapısal Eşitlik Modeliyle Araştırılması, Anadolu Üniversitesi Sosyal Bilimler Dergisi, 9(2), 1-13.

York, R. (2012). Do Alternative Energy Sources Displace Fossil Fuels?. Nature Climate Change, 2(6), 441-443.

Zecca, A., and Chiari, L. (2010). Fossil-Fuel Constraints on Global Warming. Energy Policy, 38(1), $1-3$. 
Zografakis, N., Gillas, K., Pollaki, A., Profylienou, M., Bounialetou, F., and Tsagarakis, K. P. (2011). Assessment of practices and technologies of energy saving and renewable energy sources in hotels in Crete. Renewable Energy, 36(5), 1323-1328. 